\title{
C.W. Whitney, A. Huth, K. Kehlenbeck, K. Hammer, J. Gebauer: Field Guide to Common Homegarden Crops of Southwestern Uganda. First Edition, Kleve 2020
}

\author{
L. J. G. van der Maesen $\mathbb{B}$
}

Received: 8 June 2020/Accepted: 22 October 2020/Published online: 4 November 2020

(C) The Author(s) 2020

Most people talk some times a day about food items. How do we obtain it in the best possible way, preferably sustainably so and to the benefit of farmers, consumers and developers. If one does not know what plants or animals are being discussed, the conversation is rather idle and not productive. The names of plants and their properties in the languages of the world are important to be condensed in publications, in print and digitally. For SW Uganda a useful pictorial tool has been prepared. It allows all those who manage crops in that area, from farmer to administrator and researcher, who have either little or much knowledge of the plant wealth in the homegardens, to precisely converse about those plants. It also opens the route to consult more detailed sources of economic botany information on the web and in libraries.

In this pictorial booklet 68 crops are included. Plant names are in Latin, English and in two local languages: Runyankole and Luganda. Of each species four pictures show general view, flowers, fruits and product. Crops are ranged in a rather non-botanical way: annual crops, perennial herbaceous crops, shrubs and trees, an arrangement apparently logical to the regional farmers (we would classify tomatoes as annuals rather than as perennials, and chili pepper as an annual rather than as a shrub). Within each group the crops are ranked according to local importance, so the two coffee species are placed quite far apart. Pictograms denote the usages of each crop, including cattle fodder and social aspects of usage. A handy tool in the field, as intended. It was a (by?-)product of a collaborative project aimed at reducing post-harvest losses and value addition in East-African food chains.

Funding Open Access funding enabled and organized by Projekt DEAL.

Open Access This article is licensed under a Creative Commons Attribution 4.0 International License, which permits use, sharing, adaptation, distribution and reproduction in any medium or format, as long as you give appropriate credit to the original author(s) and the source, provide a link to the Creative Commons licence, and indicate if changes were made. The images or other third party material in this article are included in the article's Creative Commons licence, unless indicated otherwise in a credit line to the material. If material is not included in the article's Creative Commons licence and your intended use is not permitted by statutory regulation or exceeds the permitted use, you will need to obtain permission directly from the copyright holder. To view a copy of this licence, visit http://creativecommons.org/licenses/by/4.0/.

Publisher's Note Springer Nature remains neutral with regard to jurisdictional claims in published maps and institutional affiliations. 